\title{
Platelet-Derived Growth Factor (PDGF)-C Neutralization Reveals Differential Roles of PDGF Receptors in Liver and Kidney Fibrosis
}

\author{
Ina V. Martin, ${ }^{*}$ Erawan Borkham-Kamphorst, ${ }^{\dagger}$ Stephanie Zok, ${ }^{*}$ Claudia R.C. van Roeyen, ${ }^{*}$ Ulf Eriksson, ${ }^{\ddagger}$ Peter Boor ${ }^{\ddagger \delta \Phi}$ \\ Kanishka Hittatiya, $"$ Hans-Peter Fischer, ${ }^{\|}$Hermann E. Wasmuth, ${ }^{* *}$ Ralf Weiskirchen, ${ }^{\dagger}$ Frank Eitner, ${ }^{* \dagger \dagger}$ Jürgen Floege, ${ }^{*}$ and \\ Tammo 0stendorf*
}

\begin{abstract}
From the Division of Nephrology and Clinical Immunology, ${ }^{*}$ the Institute of Clinical Chemistry and Pathobiochemistry, ${ }^{\dagger}$ the Institute of Pathology, ${ }^{\S}$ and the Division of Gastroenterology and Hepatology, ** RWTH Aachen University, Aachen, Germany; the Department of Medical Biochemistry and Biophysics, Karolinska Institute, Stockholm, Sweden; the Institute of Molecular Biomedicine, "Comenius University, Bratislava, Slovakia; the Institute of Pathology," University Hospital Bonn, Bonn, Germany; and the Kidney Diseases Research, ${ }^{\dagger \dagger}$ Global Drug Development, Bayer Pharma AG, Wuppertal, Germany
\end{abstract}

Accepted for publication September 6, 2012.

*Address correspondence to Tammo Ostendorf, Ph.D., RWTH Aachen University, Division of Nephrology and Clinical Immunology, Pauwelsstr. 30, Aachen 52074, Germany. E-mail: Tostendorf@ukaachen.de.

\begin{abstract}
Platelet-derived growth factors (PDGF) are key mediators of organ fibrosis. We investigated whether PDGF- $C^{-/-}$mice or mice treated with neutralizing PDGF-C antibodies are protected from bile duct ligationinduced liver fibrosis, and we compared the effects with those of PDGF-C deficiency or neutralization on kidney fibrosis induced by unilateral ureteral obstruction. Unexpectedly, and in contrast to kidney fibrosis, PDGF-C deficiency or antagonism did not protect from liver fibrosis or functional liver impairment. Furthermore, the hepatic infiltration of monocytes/macrophages/dendritic cells and chemokine mRNA expression (CC chemokine ligand [CCL]5, CCL2, and CC chemokine receptor 2 [CCR2]) remained unchanged. Transcript expression of PDGF ligands increased in both liver and kidney fibrosis and was not affected by neutralization of PDGF-C. In kidney fibrosis, PDGF-C deficiency or antagonism led to reduced expression and signaling of PDGF-receptor (R)- $\alpha$ - and PDGFR- $\beta$-chains. In contrast, in liver fibrosis there was either no difference (PDGF- $C^{-/}$mice) or even an upregulation of PDGFR- $\beta$ and signaling (anti-PDGF- $C$ group). Finally, in vitro studies in portal myofibroblasts pointed to a predominant role of PDGF-B and PDGF-D signaling in liver fibrosis. In conclusion, our study revealed significant differences between kidney and liver fibrosis in that PDGF-C mediates kidney fibrosis, whereas antagonism of PDGF-C in liver fibrosis appears to be counteracted by significant upregulation and increased PDGFR- $\beta$ signaling. PDGF- $C$ antagonism, therefore, may not be effective to treat liver fibrosis. (Am J Pathol 2013, 182: 107-117; http://dx.doi.org/10.1016/j.ajpath.2012.09.006)
\end{abstract}

Liver fibrosis, the common end-stage of chronic liver diseases, is characterized by an accumulation of extracellular matrix proteins and is associated with high morbidity and mortality. Cytokines and growth factors are critically involved in regulating liver cell activation, proliferation, and migration, as well as extracellular matrix production. ${ }^{1}$ The PDGF family plays a key role in the pathogenesis of fibrotic diseases in the heart, lung, kidney, and liver. ${ }^{2}$ PDGF-C acts via PDGFR- $\alpha$, and it is a potent mitogen for fibroblasts and vascular smooth muscle cells in vitro. ${ }^{3,4}$ Observations in different organs suggest that PDGF-C plays an important role in the regulation of fibrosis. The first evidence of this was derived from a mouse model in which transgenic overexpression of PDGF-C in the heart induced fibroblast proliferation resulting in cardiac fibrosis, hypertrophy, and ultimately cardiomyopathy. ${ }^{4,5}$ Transgenic mice with a lungspecific PDGF-C over-expression developed massive mesenchymal cell hyperplasia and died from respiratory insufficiency immediately after birth. ${ }^{6}$ Increased PDGF-C

Supported by the Deutsche Forschungsgemeinschaft: SFB TRR57, project P14 (F.E. and T.O.); SFB TRR57, project P08 (H.E.W.); SFB TRR57, project P13 and Q3 (R.W.); SFB TRR57, project Q1 (H.P.E.); and BO 3755/1-1 (P.B.). 
Table 1 Antibodies Used in this Study

\begin{tabular}{|c|c|c|c|c|}
\hline Antibody & Cat No. & Supplier & Species & Dilution \\
\hline PDGFR type- $\alpha$ & sc-338 & Santa Cruz Biotechnology, Santa Cruz, CA & $h, m, r$ & $1: 1000$ \\
\hline PDGFR type- $\beta$ & sc-958 & Santa Cruz Biotechnology & $h, m, r$ & $1: 1000$ \\
\hline P-Tyr clone 4G10 & $05-321$ & Millipore, Schwalbach, Germany & $h, m, r$ & $1: 1000$ \\
\hline Collagen type I & $1310-01$ & Southern Biotechnology Associates, Birmingham, AL & $h, m, r$ & $1: 400$ \\
\hline $\mathrm{F} 4 / 80$ & T-2017 & BMA Dianova, Hamburg, Germany & $h, m$ & $1: 1000$ \\
\hline GAPDH & sc-32233 & Santa Cruz Biotechnology & $h, m, r$ & $1: 2000$ \\
\hline P-PDGFR- $\alpha$ mAb $(Y 754,1018)$ & 9360 & Cell Signaling Technology, Frankfurt, Germany & $h, m, r$ & $1: 1000$ \\
\hline P-PDGFR- $\beta$ mAb (Y740, 751, 771, 1009, 1021) & 9970 & Cell Signaling Technology & $h, m, r$ & $1: 1000$ \\
\hline P-Akt & 4051 & Cell Signaling Technology & $h, m, r$ & $1: 1000$ \\
\hline Akt & 2920 & Cell Signaling Technology & $h, m, r$ & $1: 1000$ \\
\hline
\end{tabular}

ERK, extracellular signal-regulated kinase; GAPDH, glyceraldehyde-3-phosphate dehydrogenase; $h$, human; m, mouse; P-, phospho-; PDGFR, plateletderived growth factor receptor; $r$, rat; SMA, smooth muscle actin.

expression has also been observed in different experimental models of organ fibrosis in heart and lung tissues. ${ }^{7,8}$

We have detected an upregulated expression of PDGF-C in fibrotic interstitial areas in murine, rat, and human kidney fibrosis. $^{9,10}$ Furthermore, specific inhibition of PDGF-C markedly reduced kidney fibrotic changes in experimental murine kidney fibrosis. ${ }^{11}$ Using two independent approaches for PDGF-C depletion in mice (ie, gene knockout, as well as a neutralizing antiserum), we observed virtually identical reductions of parameters of kidney fibrosis. ${ }^{11}$

In contrast, little is known on the functional role of PDGF-C within the liver. PDGF-C transgenic mice with a liver-specific expression of the transgene develop liver

Table 2 Primers for Real-Time RT-PCR

\begin{tabular}{|c|c|c|c|}
\hline Gene & Forward primer & Reverse primer & Probe \\
\hline \multicolumn{4}{|c|}{ Primers for detection with SYBR Green } \\
\hline GAPDH & $5^{\prime}$-GGCAAATTCAACGGCACAGT-3' & $5^{\prime}$-AGATGGTGATGGGCTTCCC $-3^{\prime}$ & \\
\hline Col3a1 & $5^{\prime}-$ TGAAGATGTCGTTGATGTGCAG-3' & 5'-GCAGTGGTATGTAATGTTCTGGGAG-3' & \\
\hline CCL2 & 5'-TGGCTCAGCCAGATGCAGT- $3^{\prime}$ & 5'-ATTGGGATCATCTTGCTGGTG-3' & \\
\hline CCL5 & 5'-AGTGCTCCAATCTTGCAGTCG-3' & 5'-CAСTTCTTCTCTGGGTTGGCA-3' & \\
\hline \multicolumn{4}{|c|}{ Primers for detection with Taqman probe } \\
\hline GAPDH & $5^{\prime}$-GGCAAATTCAACGGCACAGT-3' & $5^{\prime}$-AGATGGTGATGGGCTTCCC-3' & $\begin{array}{l}5^{\prime}-\text { AAGGCCGAGAATGGGAAGCTTG- } \\
\text { TCATC-3' }\end{array}$ \\
\hline Fn1 & 5'-GATGGAATCCGGGAGCTTTT-3' & $5^{\prime}-\mathrm{TGCAAGGCAACCACACTGAC-3^{ \prime }}$ & $5^{\prime}-\mathrm{CCGGCCTGAGGCCCTGCAG-3^{ \prime }}$ \\
\hline PDGF-A & 5'-АCTTCCTGATCTGGCCCCC-3' & 5'-TGAAGGCTGGCACTTGACG-3' & $\begin{array}{l}5^{\prime}-\mathrm{TGTGGAGGTGAAGCGCTGCAC-} \\
\text { TG-3' }\end{array}$ \\
\hline$P D G F-D$ & $5^{\prime}$-GACACTTTTGCGACTCCGC- $3^{\prime}$ & 5'-TGTGAGGTGATTGCTCTCATCTC-3' & $\begin{array}{l}5^{\prime}-\text { TTGCGCAATGCCAACCTCA- } \\
\text { GGA-3' }\end{array}$ \\
\hline PDGFR- $\alpha$ & $5^{\prime}-$ AACGGAACCTTCAGCGTGG- $3^{\prime}$ & 5'-AACTCGCTGGTCTTGAACGTC-3' & $\begin{array}{l}5^{\prime} \text {-CCTTACATCTGTGAGGCCACC- } \\
\text { GTCAAA-3' }\end{array}$ \\
\hline PDGFR- $\beta$ & 5'-GAGGCTTATCCGATGCCTTCT-3' & $5^{\prime}-\mathrm{AAACTAACTCGCCAGCGCC-3^{ \prime }}$ & $\begin{array}{l}\text { 5'-CCTGTGGCTCAAGGACAACCG- } \\
\text { TACCTT-3' }\end{array}$ \\
\hline
\end{tabular}

CCL2, CC chemokine ligand 2; CCL5, CC chemokine ligand 5; CCR2, CC chemokine receptor 2; Col1a1, collagen 1a1; Col3a1, Collagen 3a1; Fn1, fibronectin 1; GAPDH, glyceraldehyde 3-phosphate dehydrogenase; PDGF, platelet-derived growth factor; PDGFR, PDGF-receptor. 
fibrosis, steatosis, and hepatocellular carcinoma. ${ }^{12}$ Therefore, we hypothesized that specific PDGF-C neutralization protects from liver fibrosis. We studied the potential profibrotic role of PDGF-C by using a neutralizing antiPDGF-C antiserum in experimental murine liver fibrosis induced by bile duct ligation (BDL) and by inducing liver fibrosis in $P D G F-C^{-/-}$mice in the same model.

\section{Materials and Methods}

\section{Anti-PDGF-C Antibody}

The generation and specificity of neutralizing sheep antiPDGF-C antibody and irrelevant sheep control IgG (kindly provided by Arne Östman, Karolinska Institute, Stockholm, Sweden) have been described. ${ }^{11}$ Briefly, anti-PDGF-C antiserum was generated in sheep after immunization with recombinant core domain of PDGF-CC and was purified using a sheep IgG purification kit (Affiland, Ans, Belgium). Control irrelevant sheep IgG were purified from nonimmunized sheep serum.

\section{Animal Experiments}

All studies were approved by the local Institutional Review Board. Animals were held in rooms with constant temperature and humidity, 12 hour light/12 hour darkness cycles, and had ad libitum access to drinking water (ozone-treated and acidified) and standard murine chow. Male C57BL/6 mice were purchased from Charles River (Sulzfeld, Germany). $P D G F-C^{-1-}$ mice were provided by Andras Nagy (Samuel Lunenfeld Research Institute, Mount Sinai Hospital, Toronto, Canada) and Christer Betsholtz (Department of Medical Biochemistry and Biophysics, Karolinska Institute, Stockholm, Sweden) and are described elsewhere. ${ }^{13}$ When bred in a mixed genetic background (between SV129 and C57BL/6), PDGF-C deficiency did not cause perinatal lethality. PDGF-C deficiency and/or wild-type (WT) status were confirmed by PCR.

\section{Liver Fibrosis}

All mice underwent an abdominal section and a double ligation of the common bile duct with 5-0 suture under anesthesia (inhalation of isoflurane) using a protocol that was adapted from rat surgery. ${ }^{14,15}$ In a first experiment, BDL was induced in 11-week-old PDGF- $C^{-1-}$ mice $(n=5)$ and WT littermate controls $(n=8)$. In a second approach, BDL was induced in WT mice treated with neutralizing anti-PDGF-C antibody (10 mg/kg intraperitoneally) or equivalent amounts of control IgG ( $n=8$ per group). Antibodies were administered twice weekly for a total of two weeks at days 1, 3, 7, 10 , and 14. Mice were sacrificed at day 14 in both experiments. At the time of sacrifice, serum was taken and liver tissue was harvested for histology and immunohistochemistry, as well as RNA and protein analyses.

\section{Kidney Fibrosis}

Unilateral ureteral obstruction (UUO) was induced in $P D G F-C^{-1-}$ mice $(n=5)$ and littermate controls $(n=7)$, as well as in WT mice treated with neutralizing anti-PDGF-C antibody $(n=5)$ or control $\operatorname{IgG}(n=5)$, as described. ${ }^{11}$ Briefly, antibody treatment of WT mice started on day 1 and was continued until day 4 after UUO with single daily intraperitoneal injections of the compound ( $1 \mathrm{mg} / \mathrm{mouse} /$ day). Mice were sacrificed at day 5 after UUO and kidney tissue was obtained from the obstructed and nonobstructed kidney for (immune) histology, as well as RNA and protein analyses.
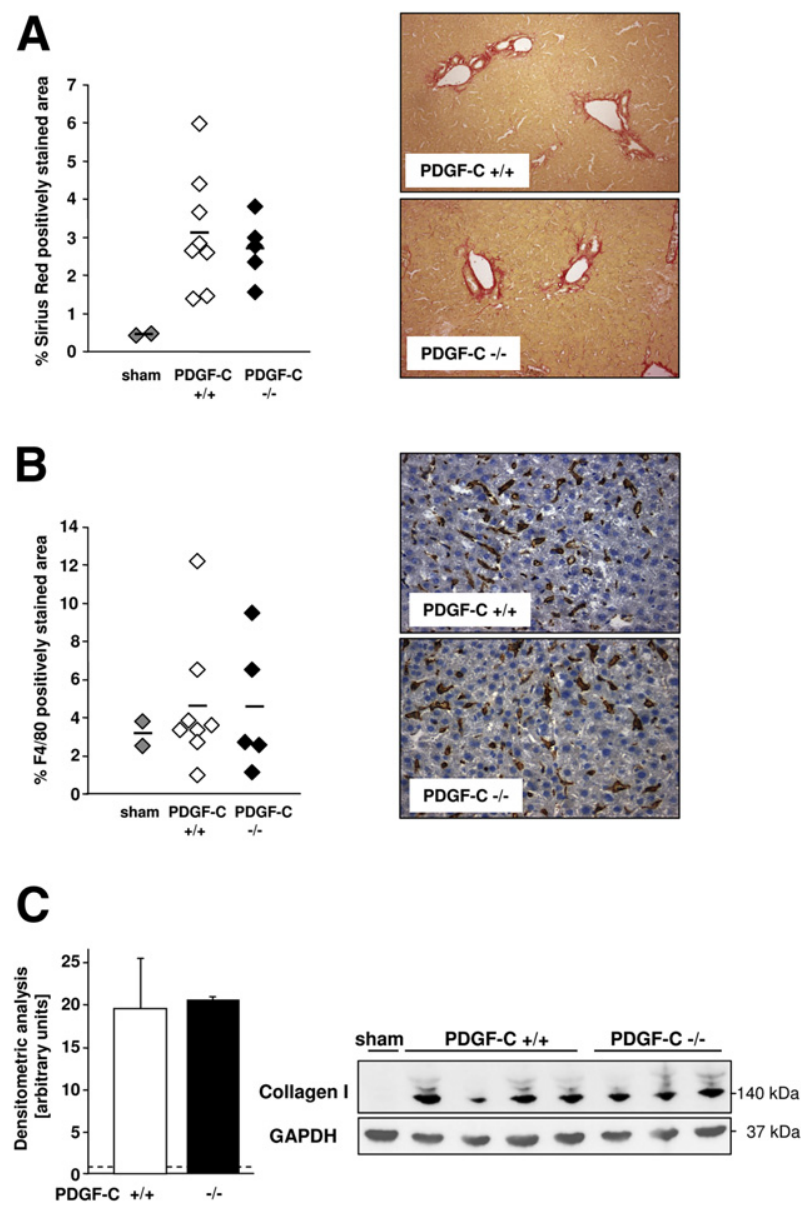

Figure 1 Quantification of BDL-induced liver fibrosis in $\mathrm{PDGF}-\mathrm{C}^{+/+}$or PDGF- $C^{-1}$ mice. A: Histological collagen deposition was analyzed by computer-assisted morphometry in Sirius Red-stained liver tissues from sham controls $(n=2)$, PDGF-C $C^{+/+}$mice $(n=8)$, or PDGF-C ${ }^{-/-}$mice $(n=5)$. Graphs show individual data from each mouse; bars indicate means. The images illustrate representative liver fibrosis (magnification, $\times 100$ ). B: Histological macrophage accumulation was analyzed by computer-assisted morphometry in F4/80-stained liver tissues (magnification, $\times 200)$. C: Representative Western blot analyzed collagen type I (and GAPDHcontrol) protein expression in total liver protein extracted from one sham control, four PDGF- $C^{+/+}$, and three PDGF- $\mathrm{C}^{-/-}$mice. Bars indicate mean relative band intensities of both groups $(n=8$ PDGF-C $C^{+/+}, n=5$ PDGF- $C^{-/-}$; dotted line indicates sham treated, nonfibrotic animals). 

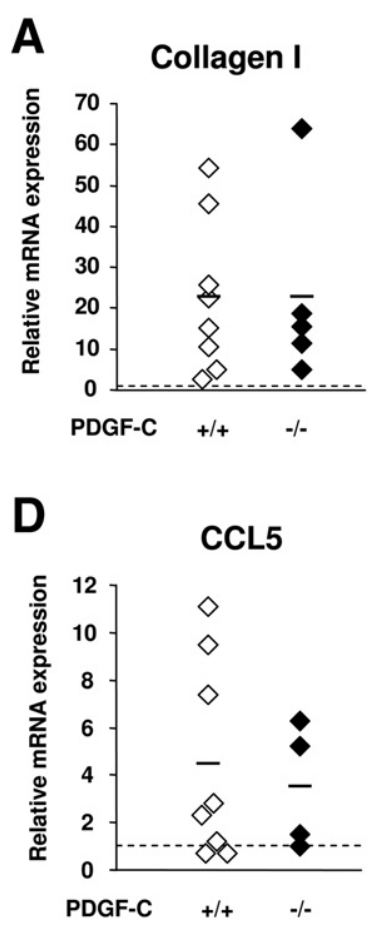

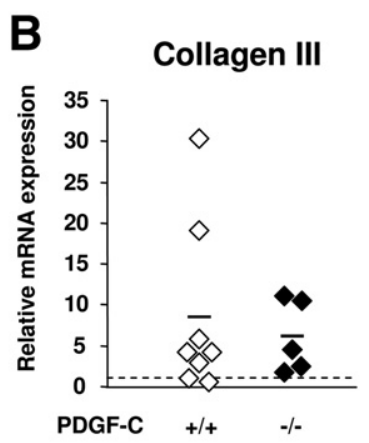

E

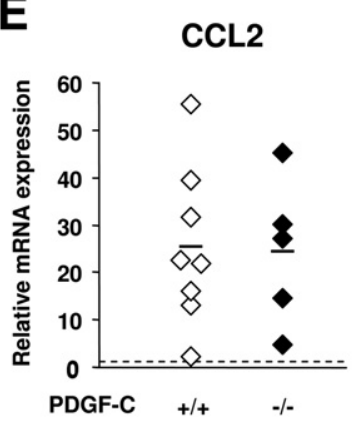

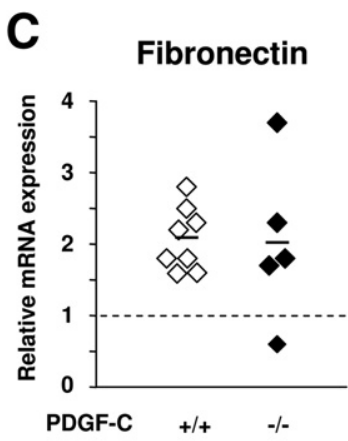

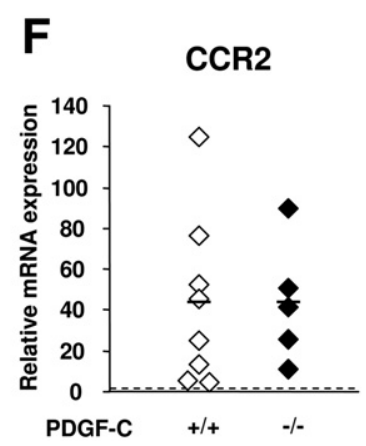

Figure 2 Quantification of liver mRNA expression $\mathrm{BDL}$-induced liver fibrosis in $P D G F-C^{+/+}$ or $P D G F-C^{-/-}$mice. Transcript expression of matrix components collagen type I (A), collagen type III (B), and fibronectin (C), as well as of inflammatory parameters CCL5 (D), CCL2 (E), and CCR2 (F) were analyzed in livers from $P D G F-C^{+/+}$mice $(n=8)$ or PDGF- $C^{-/-}$mice $(n=5)$. Dotted lines indicate sham treated, nonfibrotic animals.

\section{Liver Morphology and Immunohistochemical Analysis}

Tissues were fixed in methyl Carnoy's solution. Three-micron paraffin sections were stained with Sirius Red. Immunohistochemical analyses were performed as described ${ }^{10,11}$ using the antibodies shown in Table 1. Negative controls for the immunohistochemical procedure consisted of substitution of the primary antibody with nonimmune IgG. For the quantification of positively stained areas 20 randomly selected periportal fields were photographed and evaluated by computer-based morphometry using the analysis version 3.1 software (Soft Imaging System $\mathrm{GmbH}$; Münster, Germany). All analyses were performed in a blinded manner.

\section{Western Blot Analyses}

Frozen liver tissues were homogenized with a tight-fitting Dounce homogenizer in $0.6 \mathrm{~mL}$ protein extraction buffer $(50$ $\mathrm{mmol} / \mathrm{L}$ Hepes, $\mathrm{pH} 7.5,150 \mathrm{mmol} / \mathrm{L} \mathrm{NaCl}, 1.5 \mathrm{mmol} / \mathrm{L}$ $\mathrm{MgCl}_{2}, 1 \mathrm{mmol} / \mathrm{L}$ EGTA, $10 \%$ glycerol, $1 \%$ Triton X-100, pH 7.0) implemented with a protein and phosphatase inhibitor cocktail (1\%; Sigma-Aldrich, Taufkirchen, Germany). After incubation on ice for 5 minutes, the samples were subjected to ultrasound treatment $(3 \times 10$ seconds $)$ and centrifuged for 5 minutes at 13,000 rpm. The supernatant was taken and protein content was measured in a bicinchoninic acid protein assay, according to the manufacturer's instructions (Uptima, Montlucon Cedex, France).

For Western blot analyses $40 \mu \mathrm{g}$ of whole protein lysates were loaded in each lane and separated on a $4 \%$ to $12 \%$
NuPAGE gradient gel (Invitrogen, Karlsruhe, Germany). Proteins were transferred to nitrocellulose membranes (pore size, $0.45 \mu \mathrm{m}$; Schleicher and Schuell, Keene, $\mathrm{NH}$ ) and probed with the antibodies listed in Table 1 . The primary antibodies were detected with horseradish peroxidase-conjugated anti-goat or anti-rabbit antibodies and were visualized with the SuperSignal chemiluminescent substrate (Pierce Thermo Scientific, Rockford, IL) after extensive washing of the membranes. The

Table 3 Serum Parameters of PDGF-C $C^{+/+}$and $P D G F-C^{-/-}$Mice 14 Days after Bile Duct Ligation

\begin{tabular}{lcll}
\hline & $\begin{array}{l}\text { PDGF-C } \\
\text { BDL }^{*} \\
(n=8)\end{array}$ & $\begin{array}{l}\text { PDGF-C } \\
\text { BDL }^{*} \\
(n=5)\end{array}$ & $\begin{array}{l}\text { Control } \\
(n=2)^{\dagger}\end{array}$ \\
Parameter & $15.3 \pm 5.3$ & $13.2 \pm 4.8$ & $<0.1 /<0.1$ \\
\hline $\begin{array}{l}\text { Bilirubin (total) } \\
\quad(\mathrm{mg} / \mathrm{dL})\end{array}$ & & & \\
Bilirubin (direct) & $15.1 \pm 5.2$ & $12.8 \pm 4.8$ & $<0.1 /<0.1$ \\
$\quad(\mathrm{mg} / \mathrm{dL})$ & & & \\
Protein (g/L) & $39.5 \pm 6.7$ & $42.0 \pm 10.4$ & $40 / 42$ \\
Albumin (g/L) & $25.8 \pm 4.2$ & $27.0 \pm 5.1$ & $20.6 / 29.6$ \\
Triglycerides (mg/dL) & $69.3 \pm 20.8$ & $78.0 \pm 17.5$ & $62 / 64$ \\
Cholesterol (mg/dL) & $481 \pm 221$ & $517 \pm 317$ & $64 / 54$ \\
HDL (mg/dL) & $8.13 \pm 7.24$ & $5.2 \pm 4.92$ & $48 / 44$ \\
LDL (mg/dL) & $18.6 \pm 13.9$ & $14.2 \pm 11.6$ & $10 /<3$ \\
AST (U/L) & $876 \pm 990$ & $863 \pm 620$ & $126 / 48$ \\
ALT (U/L) & $630 \pm 827$ & $504 \pm 256$ & $78 / 24$ \\
AP (U/L) & $416 \pm 537$ & $568 \pm 796$ & $4 / 8$ \\
\hline
\end{tabular}

${ }^{*}$ There were no significant differences between both BDL groups ( $t$-test).

'Values for each animal $(n=2)$ are shown.

ALT, alanine transaminase; AP, alkaline phosphatase; AST, aspartate transaminase; $B D L$, bile duct ligation; control, non-BDL sham-treated PDGF- $\mathrm{C}^{+/+}$littermates; HDL, high-density lipoprotein; LDL, low-density lipoprotein. 
intensity of the signals was quantified using the Quantity One software 4.6 Basic (BIO-RAD, Munich, Germany).

\section{Immunoprecipitation}

For immunoprecipitation of PDGFR- $\alpha, 1 \mathrm{mg}$ of tissue lysates were pre-cleared with protein $\mathrm{G}$ agarose for 1 hour, and the supernatants were incubated with $1 \mu \mathrm{g}$ of PDGFR- $\alpha$ antibody overnight, followed by protein agarose precipitation. After washing, the precipitated samples were solubilized in lithium dodecyl sulfate sample buffer, with dithiothreitol as a reducing reagent and the resulting supernatant separated in $4 \%$ to $12 \%$ Bis-Tris gel and immunoblotted onto the nitrocellulose membranes. Membranes were probed for phosphoTyr or phospho-PDGFR- $\alpha$ and for total PDGFR- $\alpha$ to confirm the immunoprecipitation efficiency. All antibodies used are listed in Table 1.

\section{Quantitative Real-Time PCR}

Total RNA was extracted from liver and kidney tissue and cDNA syntheses, and real-time quantitative PCRs were performed as previously described. ${ }^{16}$ TaqMan primers were designed from sequences in the GenBank database using Primer Express software for Real-Time PCR, version 3.0 (Applied Biosystems, Darmstadt, Germany). The sequences used in this study are listed in Table 2. Glyceraldehyde-3phosphate dehydrogenase (GAPDH) cDNA amplification was used as an internal standard.

\section{Portal Fibroblast Cell Culture Experiments}

Portal fibroblasts were isolated from male Sprague-Dawley rats (500 to $750 \mathrm{~g}$ ), as described. ${ }^{17,18}$ To assess portal myofibroblast proliferation induced by PDGF ligands and transforming growth factor- $\beta 1$, cells were seeded at 50,000 cells per well in 12-well cultured plates using Dulbecco's modified Eagle's medium containing $10 \%$ fetal calf serum. On $70 \%$ confluence, cells were starved in $0.5 \%$ fetal calf serum for 24 hours and subsequently stimulated by adding $25 \mathrm{ng} / \mathrm{mL}$ of 1 of 4 PDGF isoforms or $1 \mathrm{ng} / \mathrm{mL}$ transforming growth factor- $\beta 1$ (R\&D Systems, Wiesbaden, Germany). Cells were labeled with $10 \mu \mathrm{mol} / \mathrm{L}$ 5-bromo-2'-deoxyuridine (BrdU) for 24 hours using the Cell ELISA BrdU colorimetric assay kit (Roche Diagnostics, Mannheim, Germany) according to the manufacturer's instructions. For Western blot analyses of lysates from stimulated portal myofibroblast cell lysates were prepared in radioimmunoprecipitation assay buffer containing $20 \mathrm{mmol} / \mathrm{L}$ Tris- $\mathrm{HCl}$ ( $\mathrm{pH} \mathrm{7.2),} 150 \mathrm{mmol} / \mathrm{L} \mathrm{NaCl}, 2 \%$ (w/v) NP-40, $0.1 \%(\mathrm{w} / \mathrm{v})$ SDS, $0.5 \%(\mathrm{w} / \mathrm{v})$ sodium deoxycholate, and the Complete Protease Inhibitors solution (Roche Diagnostics). Equal amounts $(20 \mu \mathrm{g} / \mathrm{lane})$ of total protein were then separated under reducing conditions in $4 \%$ to $12 \%$ Bis-Tris gradient gels using NuPAGE MOPS or NuPAGE MES running buffer (all Invitrogen reagents). Separated proteins were electroblotted onto nitrocellulose membranes and specific proteins were detected as previously outlined.

\section{Serum Measurements}

Total and direct bilirubin, alanine aminotransferase, aspartate aminotransferase, alkaline phosphatase total protein, HDL, LDL, cholesterol, and triglycerides were measured on a Modular Pre-Analytics system (Roche Diagnostics).

\section{Statistical Analysis}

All results are presented as means \pm SD. Statistical significance (defined as $P<0.05$ ) was evaluated using the unpaired Student's $t$-test.
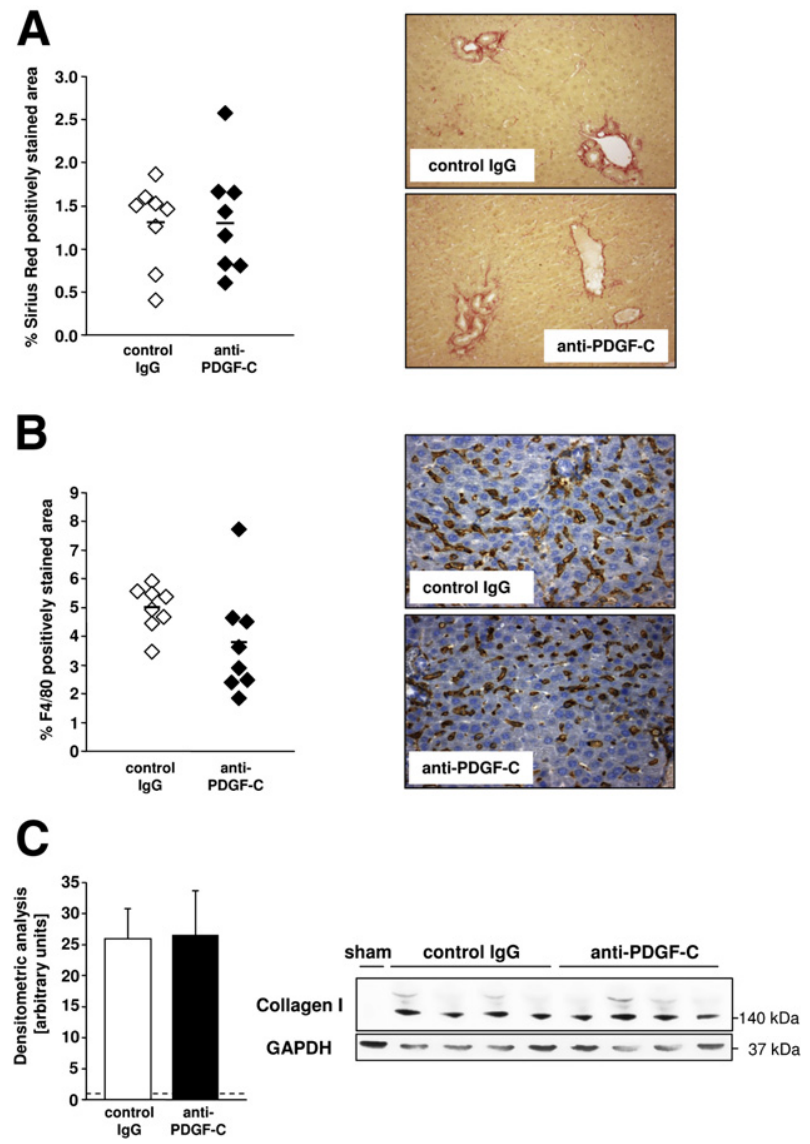

Figure 3 Quantification of BDL-induced liver fibrosis in wild-type mice treated with control IgG or neutralizing anti-PDGF-C antibody. A: Histological collagen deposition was analyzed by computer-assisted morphometry in Sirius Red-stained liver tissues from mice treated with control IgG $(n=8)$ or mice treated with neutralizing anti-PDGF-C antibody $(n=8)$. Graphs show individual data from each mouse; bars indicate means. Images illustrate representative liver fibrosis (magnification, $\times 100$ ). B: Histological macrophage accumulation was analyzed by computer-assisted morphometry in F4/80-stained liver tissues (magnification, $\times 200$ ). C: Representative Western blot analyzed collagen type I (and GAPDH control) protein expression in total liver protein extracted from one sham control, four mice treated with control IgG, and four mice treated with neutralizing anti-PDGF-C antibody. Bars indicate mean relative band intensities of both groups $\left(n=8 \mathrm{PDGF}^{-C^{+/+}}, n=8 \mathrm{PDGF}^{-C^{-/-}}\right.$; dotted line indicates shamtreated, nonfibrotic animals). 

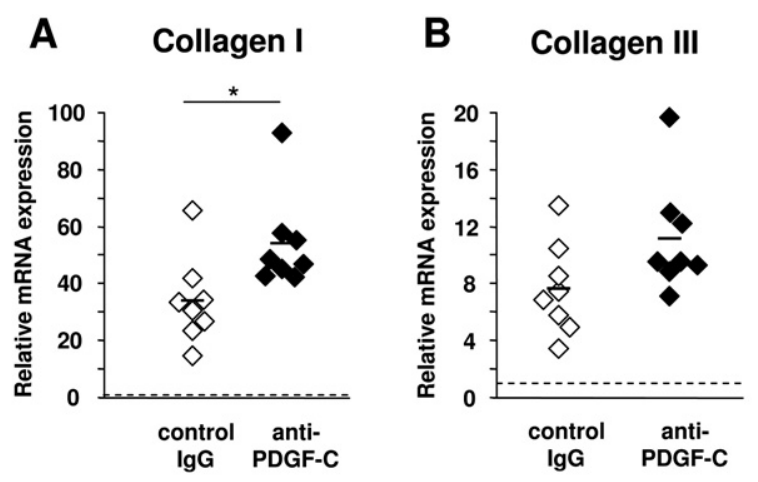

\section{Fibronectin}
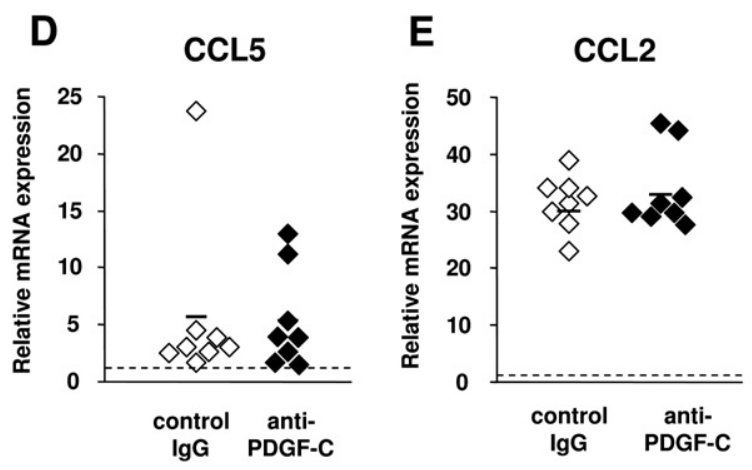
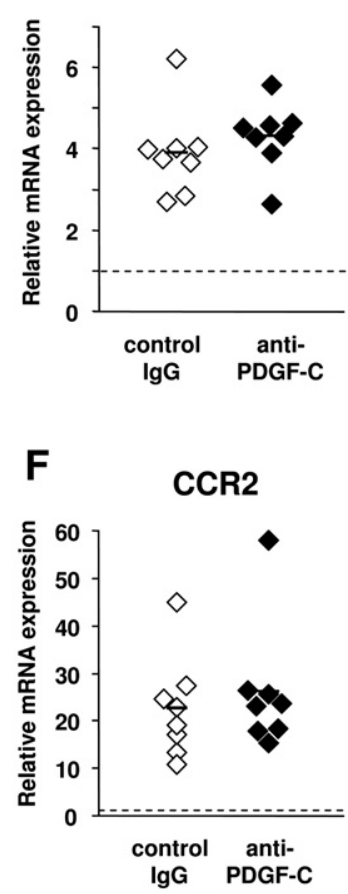

Figure 4 Quantification of liver mRNA expression after BDL-induced liver fibrosis in mice treated with control IgG or neutralizing antiPDGF-C antibody. Transcript expression of matrix components collagen type I (A), collagen type III (B), and fibronectin (C) as well as of inflammatory parameters CCL5 (D), CCL2 (E), and CCR2 (F) was analyzed in livers from mice treated with control IgG $(n=8)$ or neutralizing anti-PDGF-C antibody $(n=8)$. Dotted lines indicate shamtreated, non-fibrotic animals.

\section{Results}

PDGF-C Deficiency or Treatment With a Neutralizing Anti-PDGF-C Antibody Does Not Protect From Murine Bile Duct Ligation-induced Liver Fibrosis

Liver fibrosis was first induced in $P D G F-C^{-/-}$mice and in WT littermates. Fourteen days after bile duct ligation, significant liver fibrosis was observed, paralleled by an

Table 4 Serum Parameters of Control IgG and Anti-PDGF-C-Treated Mice 14 Days after Bile Duct Ligation

\begin{tabular}{|c|c|c|c|}
\hline Parameter & $\begin{array}{l}\text { Control IgG } \\
\mathrm{BDL}^{*} \\
(n=8)\end{array}$ & $\begin{array}{l}\text { Anti-PDGF-C } \\
\mathrm{BDL}^{*} \\
(n=8)\end{array}$ & $\begin{array}{l}\text { Control } \\
(n=3)\end{array}$ \\
\hline $\begin{array}{l}\text { Bilirubin (total) } \\
(\mathrm{mg} / \mathrm{dL})\end{array}$ & $24.8 \pm 4.0$ & $23.9 \pm 2.6$ & $1.0 \pm 0.0$ \\
\hline $\begin{array}{l}\text { Bilirubin (direct) } \\
\quad(\mathrm{mg} / \mathrm{dL})\end{array}$ & $24.0 \pm 3.1$ & $22.5 \pm 2.0$ & $1.0 \pm 0.0$ \\
\hline Protein $(\mathrm{g} / \mathrm{L})$ & $46.3 \pm 2.4$ & $47.6 \pm 3.1$ & ND \\
\hline Albumin $(\mathrm{g} / \mathrm{L})$ & $34.1 \pm 1.3$ & $34.5 \pm 1.9$ & $16.7 \pm 1.2$ \\
\hline Triglycerides (mg/dL) & $109 \pm 14$ & $98 \pm 14$ & n.m. \\
\hline Cholesterol (mg/dL) & $505 \pm 248$ & $434 \pm 155$ & $10.0 \pm 10.0$ \\
\hline $\mathrm{HDL}(\mathrm{mg} / \mathrm{dL})$ & $17.5 \pm 3.3$ & $18.3 \pm 3.5$ & $33.3 \pm 5.8$ \\
\hline $\mathrm{LDL}(\mathrm{mg} / \mathrm{dL})$ & $48.3 \pm 9.9$ & $58.3 \pm 17.2$ & $30.0 \pm 0.0$ \\
\hline AST (U/L) & $705 \pm 290$ & $784 \pm 272$ & $93.3 \pm 23.1$ \\
\hline $\operatorname{ALT}(\mathrm{U} / \mathrm{L})$ & $549 \pm 170$ & $581 \pm 173$ & $40 \pm 0.0$ \\
\hline $\mathrm{AP}(\mathrm{U} / \mathrm{L})$ & $1049 \pm 181$ & $1014 \pm 129$ & $5.0 \pm 0.0$ \\
\hline
\end{tabular}

*There were no significant differences between both BDL groups ( $t$-test).

ALT, alanine transaminase; AP, alkaline phosphatase; AST, aspartate transaminase; BDL, bile duct ligation; control, non-BDL, sham-treated C57BL6; HDL, high-density lipoprotein; LDL, low-density lipoprotein; ND, not determined.

increase in inflammatory parameters. Compared to WT littermates, $P D G F-C^{-/}$mice exhibited the same degree of Sirius Red-positive fibrotic areas (Figure 1A), collagen type I protein accumulation measured by Western blot (Figure 1C), and of collagen type I, collagen type III, and fibronectin mRNA expression (Figure 2, A-C). Functional liver injury, as indicated by various serum parameters, did not differ between the two groups (Table 3 ). In a second approach, liver fibrosis was induced in WT mice, which were treated with either neutralizing anti-PDGF-C antibody or irrelevant IgG control. The results were nearly identical to the first approach, in that no differences evolved between the livers of controls and PDGF-C-depleted mice (Figure 3, A and C; Figure 4, B and $\mathrm{C}$; Table 4). One exception was collagen type I mRNA expression, which increased in the livers of anti-PDGF-C antibody-treated animals (Figure 4A). Inflammatory parameters (ie, CCL2-mRNA, CCL5-mRNA, or CC chemokine receptor 2 (CCR2)-mRNA expression, or hepatic infiltration of F4/80-positive macrophages) increased in BDL. However, no difference was found between $P D G F-C^{-/}$mice and WT littermates (Figure 1B and Figure 2, D-F), or between mice treated with anti-PDGF-C antibody and control IgG-treated animals (Figure 3B and Figure 4, D-F).

\section{Differences in PDGFR Expression and Activation between Experimental Murine Liver and Kidney Fibrosis}

We have previously used the same $P D G F-C^{-/-}$mice and the same neutralizing PDGF-C antibody in a murine kidney fibrosis model, and we have been able to demonstrate 
A Liver fibrosis a PDGF-C $+/+$ - PDGF-C - -

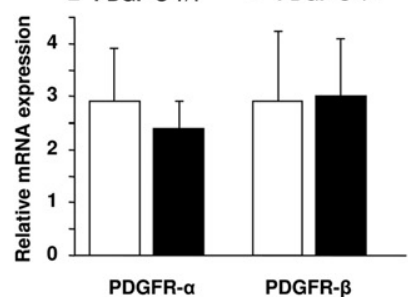

B

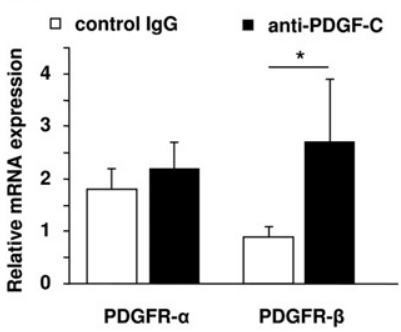

Kidney fibrosis 口 PDGF-C +/+

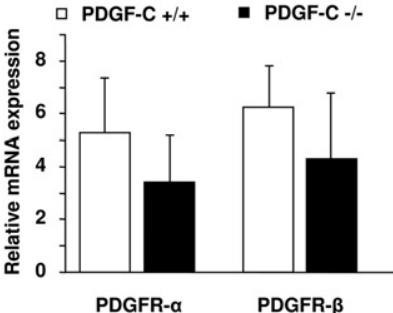

Kidney fibrosis

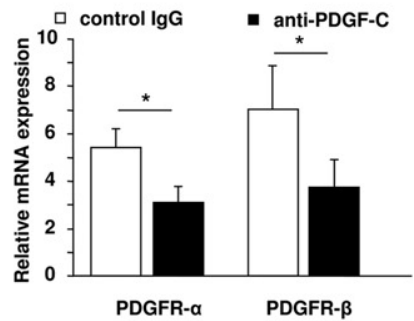

Figure 5 Quantification of hepatic and renal PDGFR- $\alpha$ and PDGFR- $\beta$ mRNA expression in experimental liver and kidney fibrosis. PDGFR- $\alpha$ and PDGFR- $\beta$ mRNA expression was analyzed in liver tissue after BDL in PDGF- $C^{+/+}(n=8)$ and PDGF-C ${ }^{-/-}$mice $(n=5)(\mathbf{A})$, and [in mice treated with control IgG $(n=8)$ or neutralizing anti-PDGF-C antibody $(n=8)(\mathbf{B})$ ]. PDGFR mRNA expression was analyzed in kidney tissue after unilateral ureteral obstruction in PDGF-C ${ }^{+/+}(n=7)$ and PDGF- $C^{-1-}$ mice $(n=5)(\mathbf{C})$, and in mice treated with control IgG $(n=5)$ or neutralizing anti-PDGF-C antibody $(n=5)(\mathbf{D})$.

significant anti-fibrotic effects with these approaches. ${ }^{11}$ To assess why PDGF-C deficiency or antagonism is beneficial in the kidney, but not with liver fibrosis, we next analyzed the intrahepatic versus renal expression of the PDGFR system.

PDGFR- $\alpha$ and PDGFR- $\beta$ mRNA expressions were not different in livers from $P D G F-C^{-/-}$mice compared to $P D G F-C^{+/+}$mice at day 14 after BDL (Figure 5A). For PDGFR- $\alpha$, this expression was confirmed on the protein level (Figure 6A and 6B), whereas protein expression of PDGFR- $\beta$ tended to be (nonsignificantly) increased in $P D G F-C^{-/}$ mice (Figure 6A and 6B). Western blotting for activated receptors revealed no differences for phosphorylated PDGFR- $\alpha$ (Figure 6Aand 6B), but showed a significant

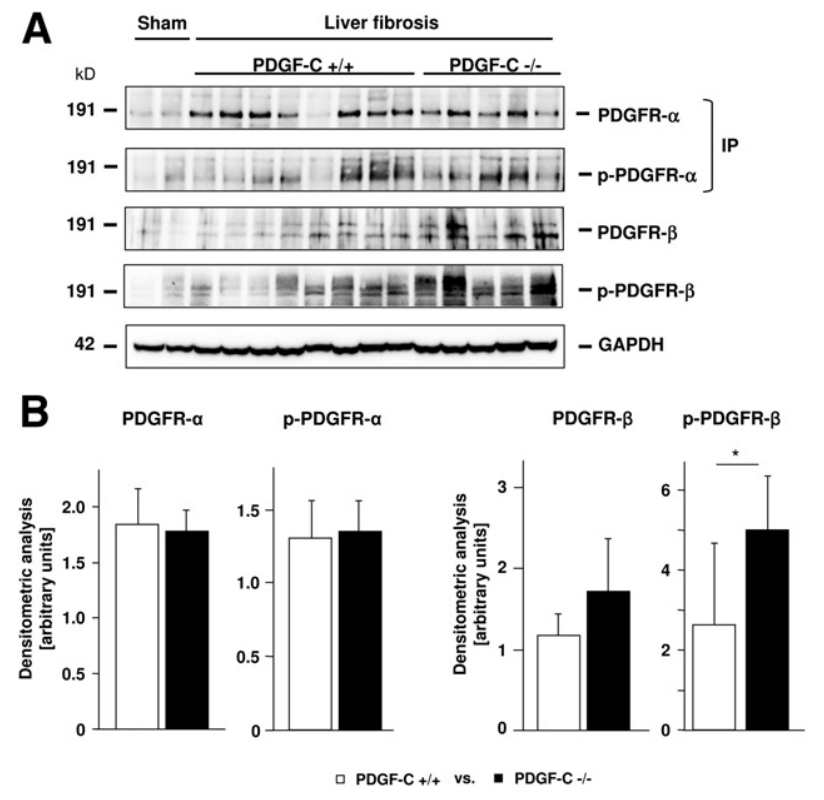

Figure 6 Hepatic expression and activation of PDGFR in PDGF-C $C^{+/+}$ and PDGF- $\mathrm{C}^{-1}$ mice after BDL. The hepatic expression of total and phosphorylated (activated) PDGFR- $\alpha$ and PDGFR- $\beta$ was analyzed in liver tissues from $P D G F-C^{+/+}$mice and $P D G F^{-/-}$mice 14 days after BDL. A: SDSPAGE and Western blot analyses with specific antibodies. PDGFR- $\alpha$ was immunoprecipitated (IP) before detection to increase the sensitivity. B: Quantification of the Western blot bands by densitometry. The GAPDH signal was used as a loading control and for normalization. increase for phosphorylated PDGFR- $\beta$ in $P D G F-C^{-1-}$ mice compared to WT littermates (Figures 6A and 6B). After treatment with neutralizing anti-PDGF-C antibody, as a second approach in BDL, we detected a significant increase of PDGFR- $\beta$ mRNA expression compared to treatment with irrelevant control $\mathrm{IgG}$, although there was no difference in PDGFR- $\alpha$ expression between these two groups (Figure 5B). In summary, these data are indicative of an upregulation of PDGFR- $\beta$ expression and activation on neutralization of PDGF-C in BDL-induced liver fibrosis, with no changes of PDGFR- $\alpha$.

In experimental kidney fibrosis induced by UUO, kidneys from $\mathrm{PDGF}-\mathrm{C}^{-/-}$mice showed a nonsignificant trend
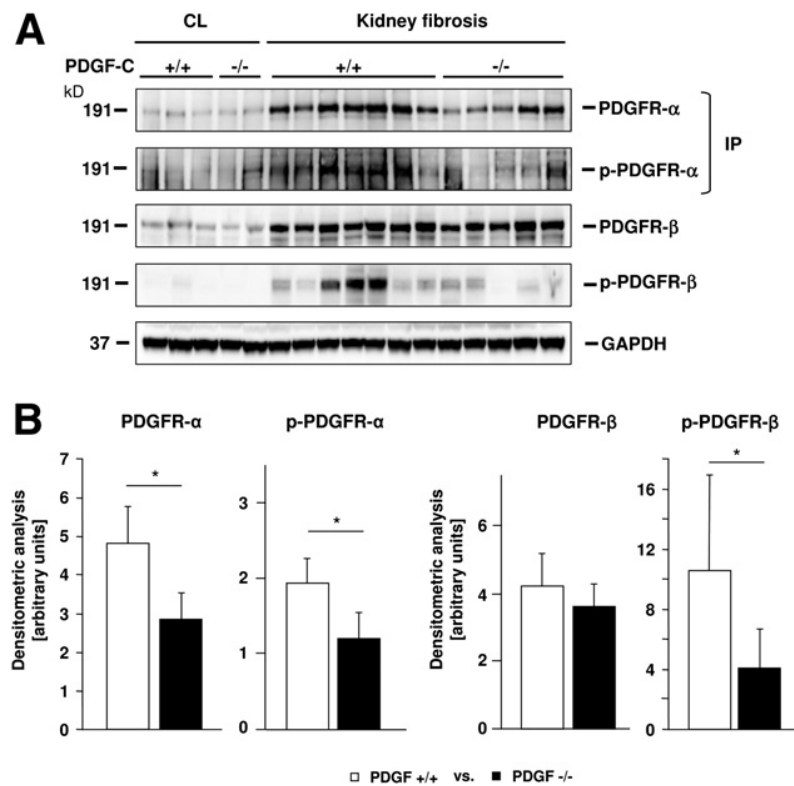

Figure 7 Renal expression and activation of PDGFR in PDGF- $\mathrm{C}^{+/+}$and $P D G F-C^{-1-}$ mice after unilateral ureteral obstruction. The renal expression of total and phosphorylated, activated PDGFR- $\alpha$ and PDGFR- $\beta$ was analyzed in kidney tissues from $P D G F-C^{+/+}$mice and $P D G F^{-/-}$mice 5 days after unilateral ureteral obstruction. A: SDS-PAGE and Western blot analyses with specific antibodies. PDGFR- $\alpha$ was immunoprecipitated (IP) before detection to increase the sensitivity. B: Quantification of the Western blot bands by densitometry. The GAPDH signal was used as a charge control and for normalization. $\mathrm{CL}$, contralateral, non-fibrotic kidneys. 


\section{$\begin{array}{llll}\text { PDGF-A } & \text { PDGF-B } & \text { PDGF-C } & \text { PDGF-D }\end{array}$}
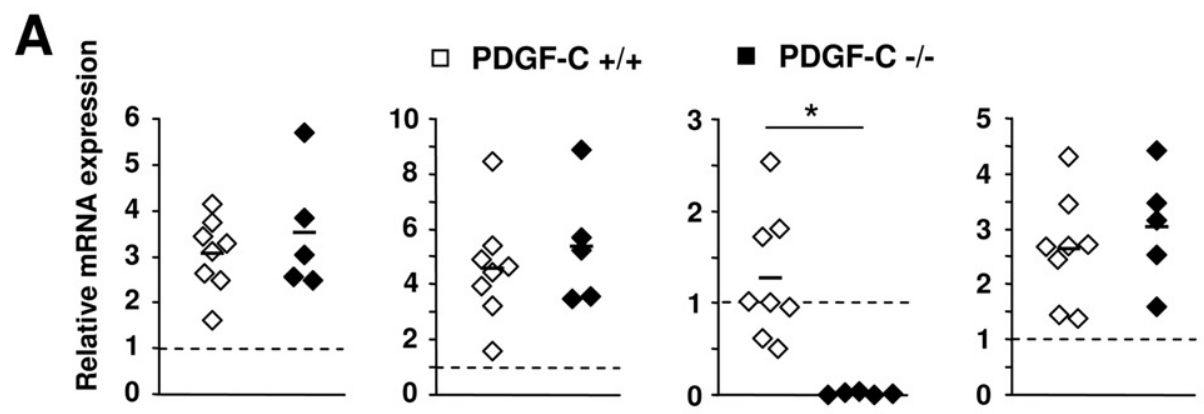

\section{Liver fibrosis}
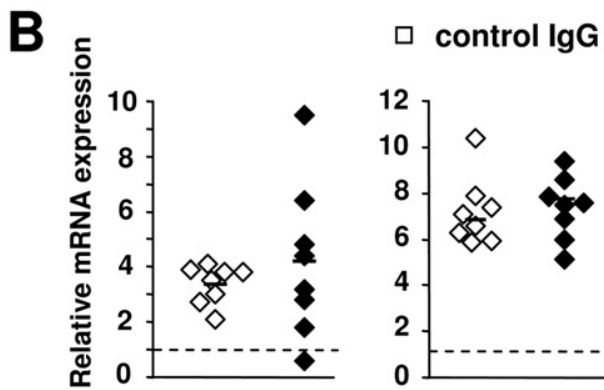

anti-PDGF-C
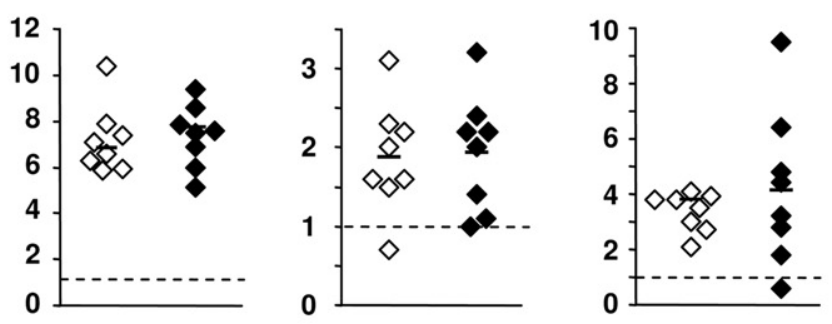

\section{Liver fibrosis}
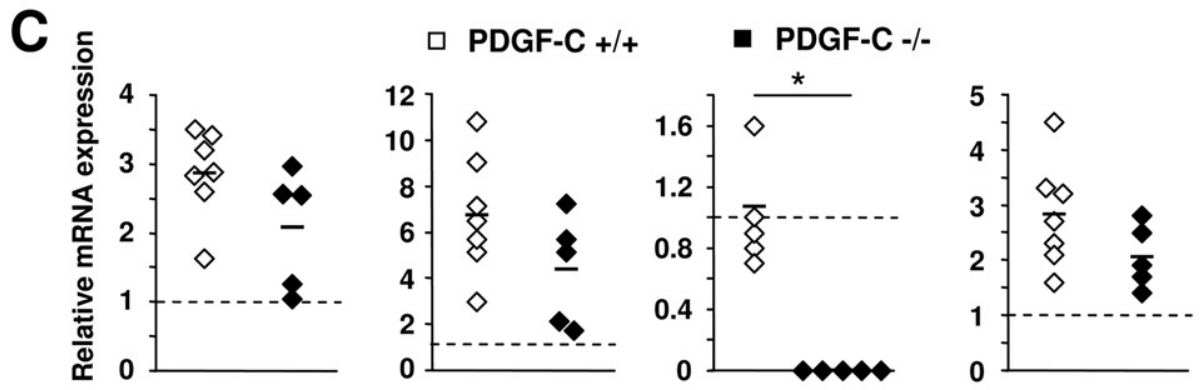

\section{Kidney fibrosis}
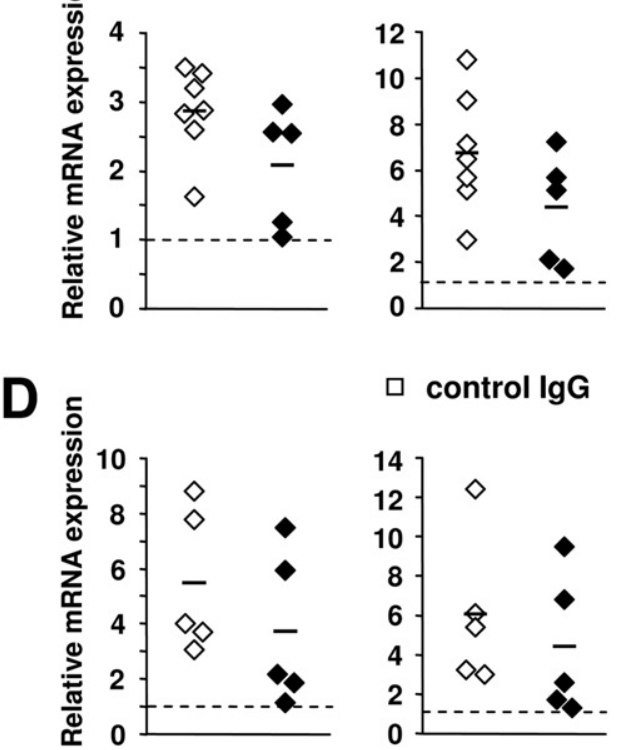

anti-PDGF-C
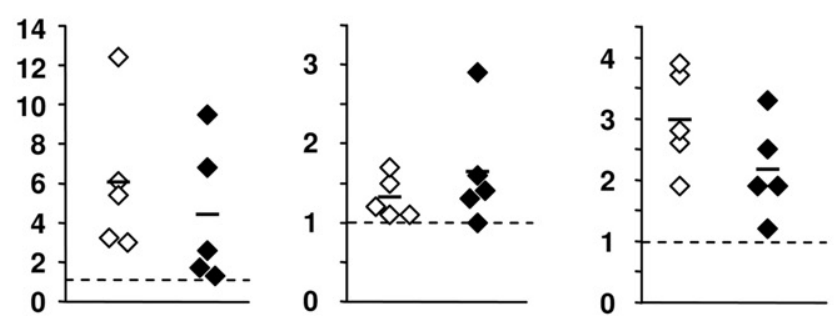

\section{Kidney fibrosis}

Figure 8 Quantification of hepatic and renal platelet-derived growth factor (PDGF) ligand mRNA expression in experimental liver and kidney fibrosis. PDGF-A, PDGF-B, PDGF-C, and PDGF-D mRNA expression was analyzed in liver tissue after bile duct ligation in PDGF-C ${ }^{+/+}(n=8)$ and PDGF-C $^{-/-}$mice $(n=5)$ $(\mathbf{A})$, and in mice treated with control IgG $(n=8)$ or neutralizing anti-PDGF-C antibody $(n=8)($ B). PDGF-A, PDGF-B, PDGF-C, and PDGF-D mRNA expression was analyzed in kidney tissue after unilateral ureteral obstruction in $P D G F-C^{+/+}(n=7)$ and $P D G F-C^{-/-}$mice $(n=5)(C)$, and in mice treated with control IgG $(n=5)$ or neutralizing anti-PDGF-C antibody $(n=5)(\mathbf{D})$. Dotted lines indicate sham-treated animals $(\mathbf{A}, \mathbf{B})$ or contralateral controls (C, D).

toward decreased PDGFR- $\alpha$ and PDGFR- $\beta$ mRNA expression in comparison to WT littermates on day 5 after disease induction (Figure 5C). Western blotting demonstrated a marked increase of renal protein expression of both PDGF receptors during UUO compared to contralateral controls (Figure 7, A and B). Renal PDGFR- $\beta$ protein expression was not different between $P D G F-C^{-/-}$mice and their WT littermates, whereas PDGFR- $\alpha$ expression was significantly reduced in $P D G F-C^{-/-}$mice (Figure 7, A and B). Demonstrated by the detection of phosphorylated PDGFR- $\alpha$ and PDGFR- $\beta$, both receptors were highly activated during UUO and this was significantly reduced in $P D G F-C^{-1-}$ mice (Figure 7, A and B). By using anti-PDGF-C antibody treatment as a second PDGF-C depleting approach in 
experimental kidney fibrosis, we detected a significant reduction of both PDGFR- $\alpha$ and PDGFR- $\beta$ mRNA (Figure 5D). Collectively, these data indicate a downregulation of PDGFR- $\alpha$ expression and activation, as well as PDGFR- $\beta$ activation on neutralization of PDGF-C in UUO-induced kidney fibrosis.

Expression of PDGF Ligands Does Not Differ between PDGF-C $C^{-/-}$Mice or PDGF-C Neutralized Mice and Their Controls

Altered expression of PDGF ligands could also have accounted for the differential activation of PDGFRs and the significant reduction of fibrosis in the kidney, but not in the liver. We, therefore, measured transcript levels of PDGF-A, PDGF-B, PDGF-C, and PDGF-D in fibrotic livers and kidneys of both $P D G F-C^{-1-}$ mice and anti-PDGF-C antibody-treated mice compared to their respective controls. As shown (in Figure 8, A and B), in liver fibrosis, PDGF-ligand transcript expression was increased compared to nondiseased controls. Neither PDGF-C deficiency nor antagonism led to differential expression of any PDGF ligand. Expectably, PDGF-C mRNA could not be detected in PDGF-C-deficient mice (Figure 8A). In fibrotic kidneys, PDGF ligand transcript expression was increased compared to contralateral kidneys and unchanged in PDGF-C-deficient or PDGF-C-neutralized mice (Figure 8, C and D). However, in contrast to the liver, there were slight reductions of PDGF ligand expression on PDGF-C depletion in the kidney. Renal PDGF-C mRNA could not be detected in $P D G F-C^{-\prime-}$ mice (Figure 8C).

\section{PDGF Isoform Signaling in Portal Myofibroblasts}

Portal myofibroblasts and bile duct epithelia in the liver proliferate markedly in the first 48 hours on BDL. Because portal myofibroblasts play an important role in early portal fibrosis, we first analyzed the expression of PDGFRs by these cells and investigated PDGF ligand-induced signaling and proliferation. Both receptors were expressed by these cells, but only stimulation with PDGF-B and PDGF-D resulted in significant signaling, as evidenced by PDGFR-Tyr phosphorylation, ERK1/2-activation, and Akt-activation (Figure 9A). In addition, all PDGF isoforms significantly induced portal myofibroblast proliferation, but PDGF-B and PDGF-D showed the strongest effects (Figure 9B).

\section{Discussion}

The major novel finding of the present study is the observation that specific inhibition of PDGF-C did not reduce experimental liver fibrosis in the murine BDL model. Using two independent approaches for PDGF-C depletion in mice (ie, gene knockout and a neutralizing antibody), we observed no differences in liver fibrosis and inflammation. These findings are in clear contrast with our own findings in experimental kidney fibrosis using the same reagents and mice. ${ }^{11}$ In the kidney, specific PDGF-C neutralization significantly reduced the development of unilateral ureteral obstruction induced fibrosis and inflammation. ${ }^{11}$

To analyze the mechanism(s) responsible for this surprising difference between the organs, as the second major finding of this study, we identified a differential regulation of PDGFR expression and signaling. PDGFR expression and signaling remained at a high level in fibrotic PDGF-C-depleted livers or even showed upregulation and enhanced signaling in the case of PDGFR- $\beta$ on treatment with anti-PDGF-C antibody. In contrast, both expression and signaling of PDGFR- $\alpha$ and PDGFR- $\beta$ were reduced in fibrotic kidneys of PDGF-C-deficient or anti-PDGF-C antibody-treated mice. This difference in PDGF receptor regulation and activation obviously accounted for the major organ difference with regard to fibrosis and inflammation on depletion or antagonism of PDGF-C. Another explanation

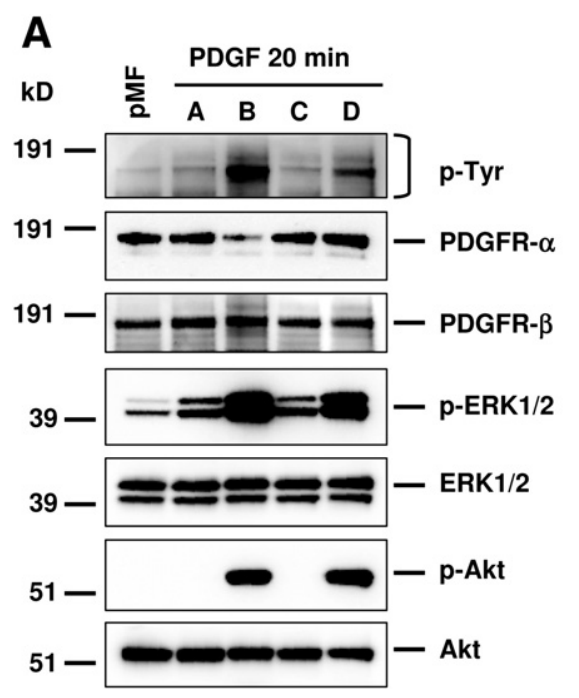

B

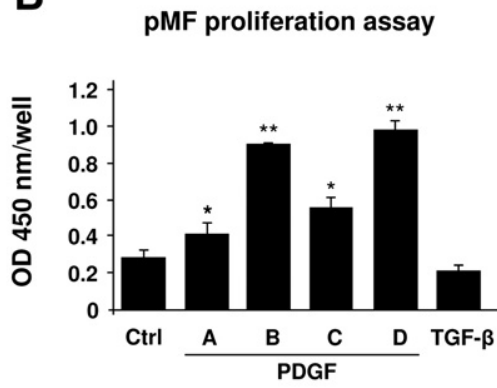

Figure 9 Platelet-derived growth factor (PDGF) isoform signaling in cultured portal myofibroblasts (pMF). A: SDS-PAGE and Western blot of pMF after 20 minutes of either no stimulation (first lane) or stimulation with PDGF isoforms (lanes 2-5) demonstrating PDGF-B and PDGF-D to be the most prominent activators of PDGFR-Tyr autophosphorylation ( $p$-Tyr) and of downstream signaling molecules phosphoERK1/2 (p-ERK1/2), and phospho-Akt (p-Akt). B: 5-bromo-2'-deoxyuridine proliferation assay. All PDGF isoforms significantly induced pMF proliferation, but PDGF-B and PDGF-D showed the strongest effects. By contrast, transforming growth factor- $\beta$ efficiently inhibited pMF proliferation. The experiments were independently performed three times with triplicate measurements. OD, optical density. 
could have been a differential, organ-specific expression of PDGF ligands. We failed, however, to detect a significant difference of PDGF ligand transcript expression in the fibrotic liver and fibrotic kidney on PDGF-C deficiency or PDGF-C neutralization. It cannot be completely excluded that there is a differential expression of the individual PDGF ligands on the protein level. In addition, during fibrosis, locally changed proteolytic activities on latent PDGF-C or PDGF-D might also play a role that can lead to reduced binding to and activation of PDGF receptors in the kidney, but not in the liver.

Is it unexpected that we were unable to identify an antifibrotic effect of PDGF-C neutralization in experimental liver fibrosis? Hepatic transcripts of PDGF ligands and receptors were upregulated on BDL-induced liver fibrosis, but with higher upregulation of PDGF-B, PDGF-D, and receptor- $\beta$ than PDGF-A, PDGF-C, and PDGFR- $\alpha .{ }^{19}$ Furthermore, primary hepatic stellate cells or myofibroblasts showed a significant proliferation only when stimulated with PDGF-B or PDGF-D, but not with PDGF-A or PDGF-C. ${ }^{19}$ This is in contrast to renal myofibroblasts, which have been demonstrated to be potently activated by PDGF-C. ${ }^{11}$ Also, during renal fibrosis, leukocyte-derived PDGF-C may induce chemokine expression by fibroblasts, which may lead to the recruitment of additional leukocytes, creating an amplification loop for renal inflammation and fibrosis. ${ }^{11}$ Accordingly, PDGF-C deficiency significantly reduced renal leukocyte infiltration ${ }^{11}$; whereas, during liver fibrosis in the present study, PDGF-C deficiency had no significant effect on the infiltration of leukocytes in the liver. We also investigated portal myofibroblasts, which play an important role in liver scar formation, especially in biliary fibrosis. ${ }^{20}$ In contrast to PDGF-A and PDGF-C, PDGF-B and PDGF-D emerged as potent inducers of PDGFR signaling and cell proliferation. Consistent with the previously described data, suggesting PDGFR- $\beta$ signaling to be more important than PDGFR- $\alpha$ signaling in liver fibrosis, a recent study demonstrated that BDL-induced murine liver fibrosis was less severe in mice treated with an anti-PDGF-B antibody. ${ }^{21}$ Furthermore, liver fibrosis has also been induced in mice by liver-specific over-expression of PDGF-B. ${ }^{22}$ Collectively, in the liver, these data point to a stronger role of PDGF-B and PDGF-D, and PDGFR- $\beta$ signaling in the formation of liver fibrosis than signaling via PDGF-C and PDGFR- $\alpha$.

The individual contributions of PDGFR- $\alpha$ and PDGFR$\beta$ signaling in the development of liver fibrosis are still incompletely understood. The present study is the first to report specific PDGF-C antagonism in experimental liver fibrosis in vivo. The lack of any therapeutic effect of an antiPDGF-C treatment (in two independent and complementary experimental settings) together with the documented benefit of an anti-PDGF-B treatment indicates that PDGFR$\beta$ signaling might be more important in the pathogenesis of liver fibrosis. The different role of PDGF-C in the development of kidney fibrosis is striking, and the lack of an up-regulation of renal PDGFR- $\beta$ expression in response to anti-PDGF-C treatment might explain the significant differences of anti-PDGF-C treatment in kidney or liver fibrosis.

In conclusion, specific PDGF-C antagonism did not protect from BDL-induced murine liver fibrosis. PDGFreceptor expression analyses identified a significant upregulation of the PDGFR- $\beta$ in response to anti-PDGF-C treatment that might have initiated a PDGFR- $\beta$-driven escape mechanism. PDGF-C antagonism, therefore, may not be a promising treatment of liver fibrosis.

\section{Acknowledgments}

We thank Sibille Sauer-Lehnen, Carmen Tag, Christiane Esch, Lydia Zimmermanns, Gertrud Minartz, Christina Gianussis, Dagmar Wieland, and Lidia Tihaa for their technical help.

\section{References}

1. Hernandez-Gea V, Friedman SL: Pathogenesis of liver fibrosis. Annu Rev Pathol 2011, 6:425-456

2. Bonner JC: Regulation of PDGF and its receptors in fibrotic diseases. Cytokine Growth Factor Rev 2004, 15:255-273

3. Gilbertson DG, Duff ME, West JW, Kelly JD, Sheppard PO, Hofstrand PD, Gao Z, Shoemaker K, Bukowski TR, Moore M, Feldhaus AL, Humes JM, Palmer TE, Hart CE: Platelet-derived growth factor C (PDGF-C), a novel growth factor that binds to PDGF alpha and beta receptor. J Biol Chem 2001, 276:27406-27414

4. Li X, Ponten A, Aase K, Karlsson L, Abramsson A, Uutela M, Backstrom G, Hellstrom M, Bostrom H, Li H, Soriano P, Betsholtz C, Heldin $\mathrm{CH}$, Alitalo K, Ostman A, Eriksson U: PDGF-C is a new protease-activated ligand for the PDGF alpha-receptor. Nat Cell Biol 2000, 2:302-309

5. Ponten A, Li X, Thoren P, Aase K, Sjoblom T, Ostman A, Eriksson U: Transgenic overexpression of platelet-derived growth factor-C in the mouse heart induces cardiac fibrosis, hypertrophy, and dilated cardiomyopathy. Am J Pathol 2003, 163:673-682

6. Zhuo Y, Hoyle GW, Shan B, Levy DR, Lasky JA: Over-expression of PDGF-C using a lung specific promoter results in abnormal lung development. Transgenic Res 2006, 15:543-555

7. Grun K, Markova B, Bohmer FD, Berndt A, Kosmehl H, Leipner C: Elevated expression of PDGF-C in coxsackievirus B3-induced chronic myocarditis. Eur Heart J 2005, 26:728-739

8. Zhuo Y, Zhang J, Laboy M, Lasky JA: Modulation of PDGF-C and PDGF-D expression during bleomycin-induced lung fibrosis. Am J Physiol Lung Cell Mol Physiol 2004, 286:L182-L188

9. Eitner F, Ostendorf T, Kretzler M, Cohen CD, Eriksson U, Grone HJ, Floege J: PDGF-C expression in the developing and normal adult human kidney and in glomerular diseases. J Am Soc Nephrol 2003, 14 $1145-1153$

10. Eitner F, Ostendorf T, Van Roeyen C, Kitahara M, Li X, Aase K, Grone HJ, Eriksson U, Floege J: Expression of a novel PDGF isoform. PDGF-C, in normal and diseased rat kidney. J Am Soc Nephrol 2002, 13:910-917

11. Eitner F, Bucher E, van Roeyen C, Kunter U, Rong S, Seikrit C, Villa L, Boor P, Fredriksson L, Backstrom G, Eriksson U, Ostman A, Floege J, Ostendorf T: PDGF-C is a proinflammatory cytokine that mediates renal interstitial fibrosis. J Am Soc Nephrol 2008, 19: 281-289

12. Campbell JS, Hughes SD, Gilbertson DG, Palmer TE, Holdren MS, Haran AC, Odell MM, Bauer RL, Ren HP, Haugen HS, Yeh MM, 
Fausto N: Platelet-derived growth factor $\mathrm{C}$ induces liver fibrosis, steatosis, and hepatocellular carcinoma. Proc Natl Acad Sci USA 2005, 102:3389-3394

13. Ding H, Wu X, Bostrom H, Kim I, Wong N, Tsoi B, O'Rourke M, Koh GY, Soriano P, Betsholtz C, Hart TC, Marazita ML, Field LL, Tam PP, Nagy A: A specific requirement for PDGF-C in palate formation and PDGFR-alpha signaling. Nat Genet 2004, 36: $1111-1116$

14. Arias M, Sauer-Lehnen S, Treptau J, Janoschek N, Theuerkauf I, Buettner R, Gressner AM, Weiskirchen R: Adenoviral expression of a transforming growth factor-betal antisense mRNA is effective in preventing liver fibrosis in bile-duct ligated rats. BMC Gastroenterol 2003, 3:29

15. Kountouras J, Billing BH, Scheuer PJ: Prolonged bile duct obstruction: a new experimental model for cirrhosis in the rat. Br J Exp Pathol 1984, 65:305-311

16. Ostendorf T, van Roeyen CR, Peterson JD, Kunter U, Eitner F, Hamad AJ, Chan G, Jia XC, Macaluso J, Gazit-Bornstein G, Keyt BA, Lichenstein HS, LaRochelle WJ, Floege J: A fully human monoclonal antibody (CR002) identifies PDGF-D as a novel mediator of mesangioproliferative glomerulonephritis. J Am Soc Nephrol 2003, 14: $2237-2247$
17. Kruglov EA, Jain D, Dranoff JA: Isolation of primary rat liver fibroblasts. J Investig Med 2002, 50:179-184

18. Meurer SK, Tihaa L, Borkham-Kamphorst E, Weiskirchen R: Expression and functional analysis of endoglin in isolated liver cells and its involvement in fibrogenic Smad signalling. Cell Signal 2011, 23:683-699

19. Borkham-Kamphorst E, van Roeyen CR, Ostendorf T, Floege J, Gressner AM, Weiskirchen R: Pro-fibrogenic potential of PDGF-D in liver fibrosis. J Hepatol 2007, 46:1064-1074

20. Beaussier M, Wendum D, Schiffer E, Dumont S, Rey C, Lienhart A, Housset C: Prominent contribution of portal mesenchymal cells to liver fibrosis in ischemic and obstructive cholestatic injuries. Lab Invest 2007, 87:292-303

21. Ogawa S, Ochi T, Shimada H, Inagaki K, Fujita I, Nii A, Moffat MA, Katragadda M, Violand BN, Arch RH, Masferrer JL: Anti-PDGF-B monoclonal antibody reduces liver fibrosis development. Hepatol Res 2010, 40:1128-1141

22. Czochra P, Klopcic B, Meyer E, Herkel J, Garcia-Lazaro JF, Thieringer F, Schirmacher P, Biesterfeld S, Galle PR, Lohse AW, Kanzler S: Liver fibrosis induced by hepatic overexpression of PDGF-B in transgenic mice. J Hepatol 2006, 45:419-428 